\title{
Use of Ustekinumab in the Treatment of Libyan Psoriasis Vulgaris Patients
}

\author{
Belkais BELTAMMER, Ali GARGOOM, Ghada TAEIB, Gamal DUWEB \\ Dermatology Department, Faculty of Medicine, Benghazi University, Benghazi-Libya \\ *Correspondence: Gamal Duweb, E-mail: drduweb@gmail.com \\ UDC 616.517-085.26:615.456(612)
}

\begin{abstract}
Introduction. Psoriasis is a relatively common chronic inflammatory disease. It clinically manifests as raised, well defined erythematous plaques with irregular borders and silvery scales. Psoriasis appears to be mediated by abnormal immune system functioning, including $T$ lymphocyte and macrophage activation and release of various cytokins, such as interleukin 12 (IL-12) and IL-23. Recently a new biologic agent Ustekinumab has been used in the treatment of psoriasis. Our aim in this study was to assess the efficacy and tolerability of ustekinumab in moderate to severe psoriasis vulgaris and to observe and report any adverse reaction. Material and Methods. Thirty five psoriatic patients above the age of 18 years having moderate to severe psoriasis were included in this study. Ustekinumab is available in pre-filled syringe $45 \mathrm{mg} / 0.5 \mathrm{ml}, 90 \mathrm{mg} / 1.0 \mathrm{ml}$ for subcutaneous injection according to body weight at the intervals of 0,4 weeks, and then every 12 weeks. It is given in hospital by a doctor or specialist nurse. The assessment of the patients' condition and improvement was carried out after administering each dose using PASI score. Results. Thirty five patients were included in this study. Baseline PASI score of our patients ranged from 11.4 to 39.8 (mean: 21.1). There was a dramatic response to treatment with ustekinumab in which PASI decreased to 6.7 after the second dose, followed by subsequent responses that reached 2.6 after the 6 th dose . After the second dose, $61 \%$ of the cases had marked improvement and $11 \%$ had clearance of their skin lesions. After the last, sixth dose there was a marked improvement in $65 \%$ of cases and the percentage of complete clearance increased to $24 \%$. Ustekinumab had positive effect on psoriatic nail changes as well-there was a significant improvement in $50 \%$ of cases and complete clearance (cure) in $24 \%$ of cases. Conclusion: Ustekinumab is effective in the treatment of severe and resistant cases of psoriasis vulgaris. It is well tolerated by the patients. No reactions or serious side effects have been reported.
\end{abstract}

Key words: Psoriasis; Ustekinumab; Dermatologic Agents; Biological Therapy; Treatment Outcome; Libya

\section{Introduction.}

Psoriasis is a relatively common chronic inflammatory disease that affects around 3\% of the general population. The incidence is highest in males at the age between 20 and 39 years and in females aged from 40 to 59 years, with an equal male-to-female ratio $(1,2)$. Psoriasis vulgaris accounts for almost $90 \%$ of the dermatological presentation of the disease.

Psoriasis is presumed to be a multifactorial disease which is provoked in genetically predisposed individuals by various triggering factors (3). Psoriasis appears to be mediated by abnormal immune system functioning, including $T$ lymphocyte and macrophage activation and release of various cytokins (4-6). These include interleukin 12 (IL-12) and IL-23. IL-12 induces differentiation of CD4+ T Cells into Th1 cells that produce type 1 cytokines such as interferon $\mathrm{g}$ and tumor necrosis factor a $(7,8)$. IL-23 induces the development of Th17 cells producing proinflammatory cytokine IL-17 $(9,10)$, which has recently been identified as mediating the tissue damage in psoriasis $(11,12)$. It has a very high negative impact on quality of life, requires a long-term treatment which usually has a high social and economic impact, and is also associated with a decreased life span $(13,14)$.

In psoriasis treatment, topical monotherapy remains the mainstay of treatment for most patients especially those with limited disease. However, 20 to $30 \%$ of people with psoriasis experience severe symptoms and may require systemic treatment such as methotrexate, cyclosporine, oral retinoids or pho- 
totherapy $(15,16)$. The following biologic agents of the anti-TNFa group are currently available at the market: etanercept, infliximab, and adalimumab. Recently a new biologic agent, ustekinumab has been used in the treatment of psoriasis. Ustekinumab is a firstin-class, fully human interleukin -12/23 p40 monoclonal antibody has demonstrated high efficacy in treating moderate to severe plaque psoriasis $(9,17)$.

Our aim in this study was to assess the efficacy and tolerability of ustekinumab in the treatment of patients with moderate to severe psoriasis, any additional effect on psoriatic nail changes and to observe its adverse effects.

\section{Material and Methods}

Thirty five Libyan psoriatic patients above the age of 18 years with moderate to severe psoriasis attending the Psoriasis Clinic of the Dermatology Department, Benghazi, Libya were included in this study over a period of 3 years (April, 2014 to April 2017). All patients had given the signed written informed consent prior to participating in the study. Detailed disease history was taken for each patient and all of them underwent complete clinical examination. The disease severity was assessed by using PASI score at each first visit. Investigations including CBC and ESR, RFT, LFT, FBS, tuberculin test, chest $X$ ray, serology test for HIV, $\mathrm{HBV}$, and HCV, ANA and Anti dsDNA were done in all patients at the baseline visit and some were repeated at each visit. Clinical assessments included dermatological examinations, vital signs, concomitant medications, monitoring for adverse events, and measures of psoriasis activity (Psoriasis Area Severity Index) (PASI). Ustekinumab is available in pre-filled syringe $45 \mathrm{mg} / 0.5 \mathrm{ml}, 90 \mathrm{mg} / 1.0 \mathrm{ml}$ for subcutaneous injection according to the body weight at the intervals of 0,4 weeks, and then every 12 weeks. It was given in hospital by a doctor or specialist nurse. Assessment of the patient's condition and improvement was carried out after each dose using PASI score. Any patient's compliant or unusual presentation or adverse reaction reported by a patient or doctor was recorded. Laboratory investigation included complete blood count, liver function test, renal function test fasting blood sugar which had been taken before administering the dose. When all data were collected, they were fed to the computer and processed using the statistical package for social sciences (for personal computer) SPSS-TC program version 11.5.

\section{Results}

Out of 35 psoriasis vulgaris patients included in our study, $72 \%$ were males and $28 \%$ were females. Their age ranged from 19 to 82 years, the mean age being 41.1 years and and their disease lasted from 3 to 25 years, the mean duration being 11.78 years. The body weight was $<100 \mathrm{~kg}$ in $72 \%$ of our patients and $>100 \mathrm{~kg}$ in $28 \%$ of them.

In $56 \%$ of our patients the disease was moderate, while in $44 \%$ of them it was severe and nail involvement was seen in $81 \%$ of our study cases. As for the previous treatment with systemic therapy including methotrexate, photochemotherpy, narrow-band UVB, cyclosporine and retinoids, the majority of our patients $(78 \%)$ received either one, two or all of them. Twenty five patients $(71.4 \%)$ received $45 \mathrm{mg}$ of ustekinumab.

The baseline PASI score of our patients ranged from 11.4 to 39.8 , the mean being 21.1. Figure 1 illustrates one of the most severely affected patients with highest score. There was a dramatic response to treatment with ustekinumab in which PASI decreased to 6.7 after the

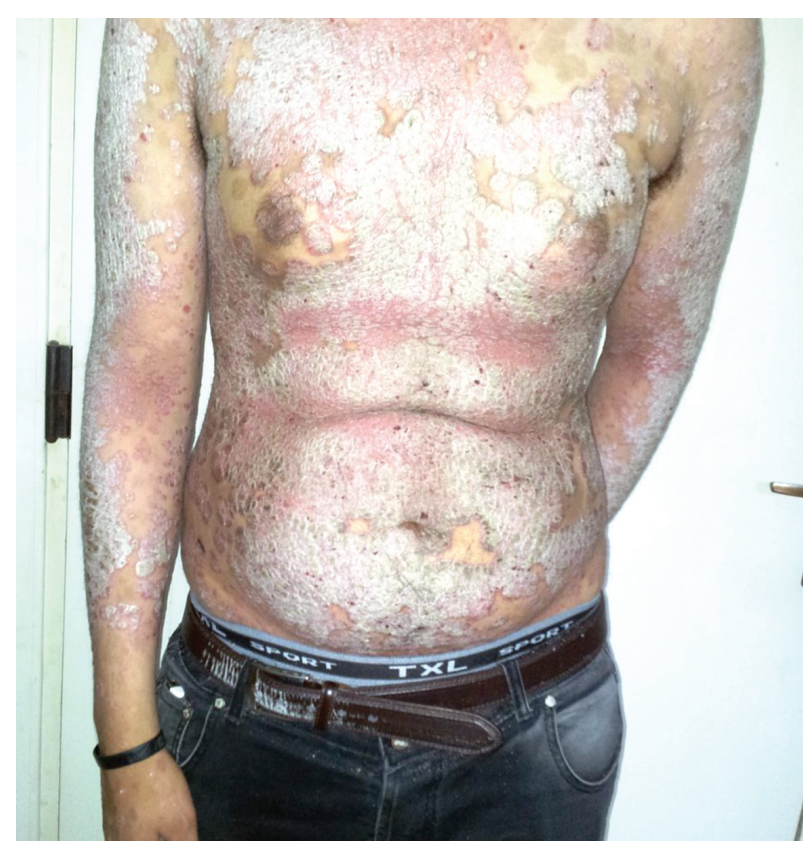

Figure 1. The patient before treatment 


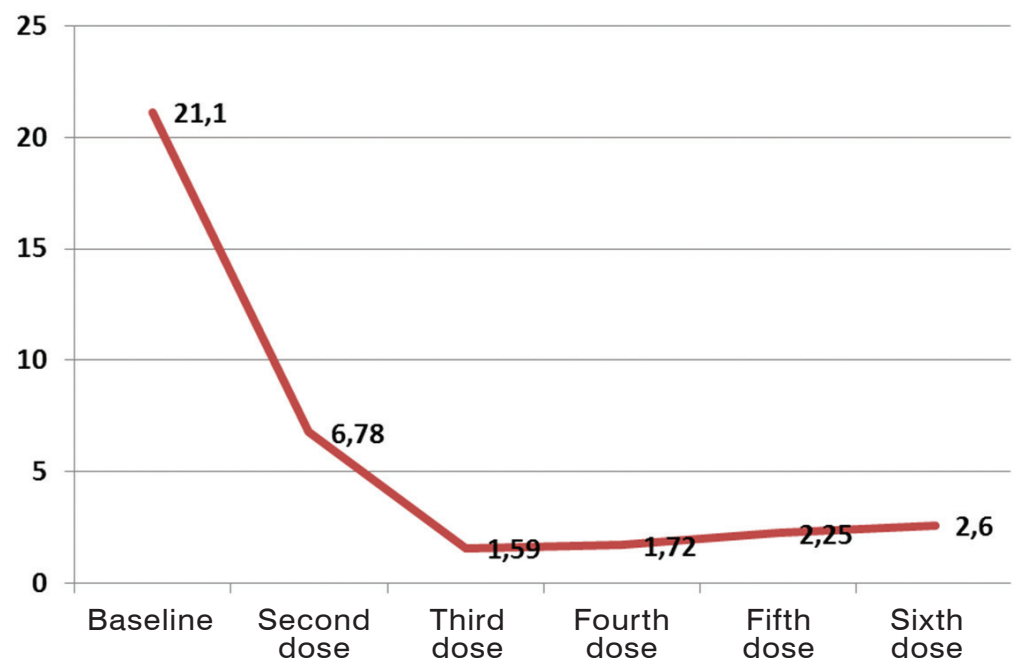

Figure 2. PASI changes during the treatment course

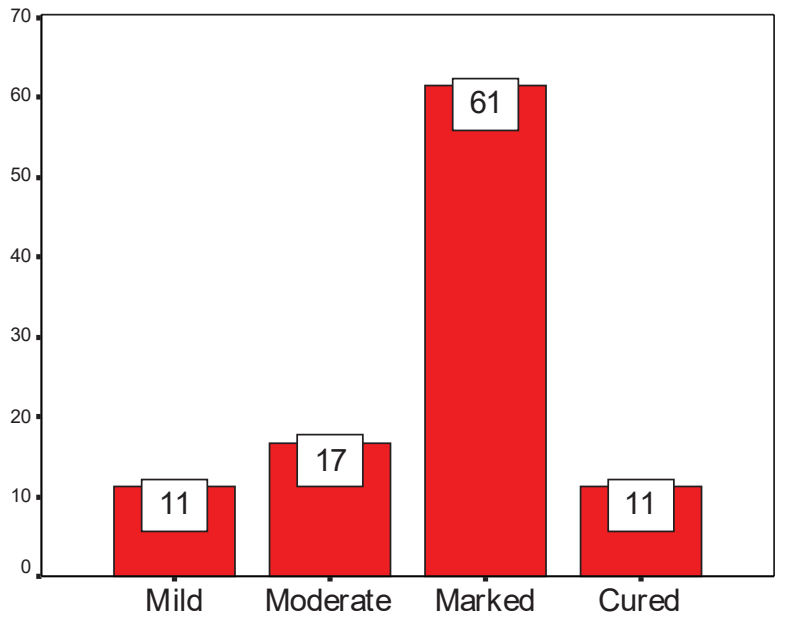

Figure 3. Improvement after the second dose

second dose, followed by subsequent responses that reached 2.6 after the 6th dose (Figure 2). After the second dose $61 \%$ of the cases had marked improvement and $11 \%$ had clearance of their skin lesions (Figures 3 and 4). Also the efficacy was great and $75 \%$ improvement was seen in $27(78 \%)$ patients and $90 \%$ improvement was seen in 25 patients after the third dose. After the last, 6th dose, a significant improvement was observed in $65 \%$ of cases and the percentage of clearance increased to $24 \%$ (Figures 5 and 6 ). An additional effect of ustekinumab was observed on the psoriatic nail and nail changes significantly improved in $50 \%$ of our cases and there was the complete clearance in $24 \%$ of them at the

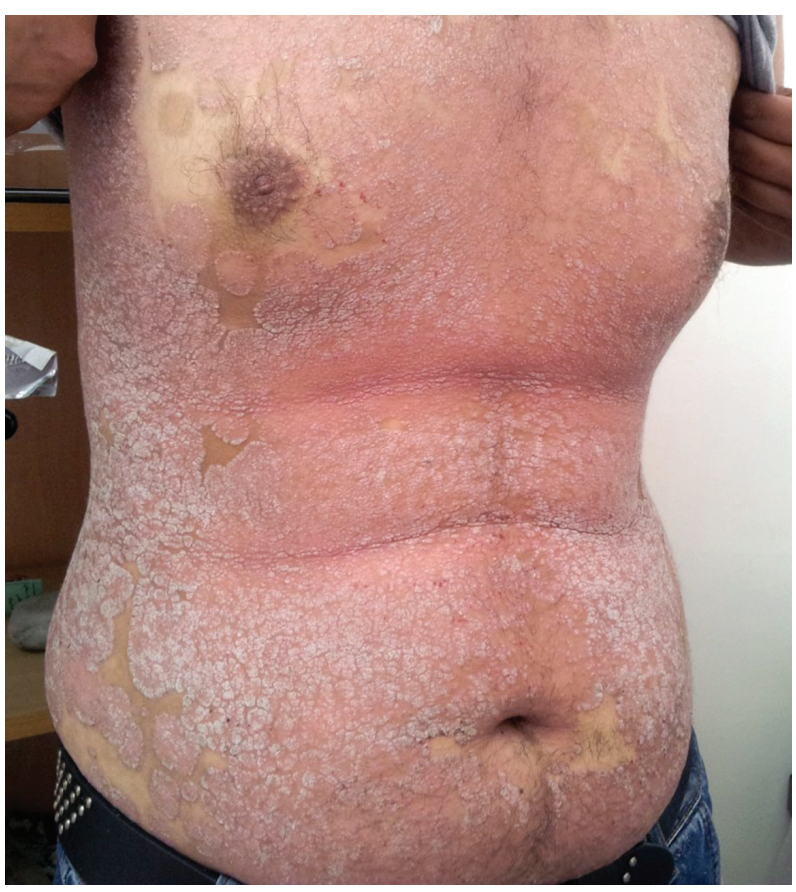

Figure 4. The photo of the same patient after the second dose

end of treatment. Out of 7 patients (25\%) who had presented with joint pains, stiffness and/or swelling seen in our study, moderate to marked improvement was achieved in 4 patients. No side effects were reported either by the patients or the doctor. 


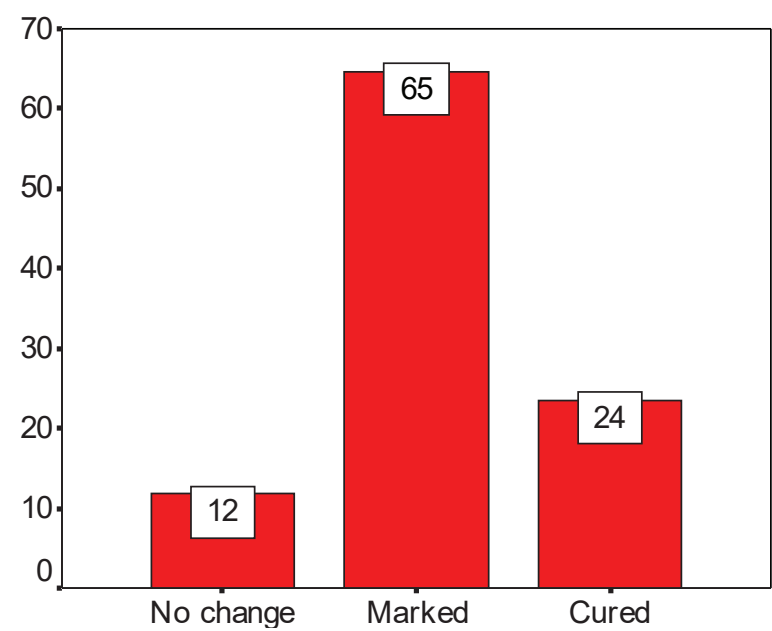

Figure 5. Improvement after the last, sixth dose

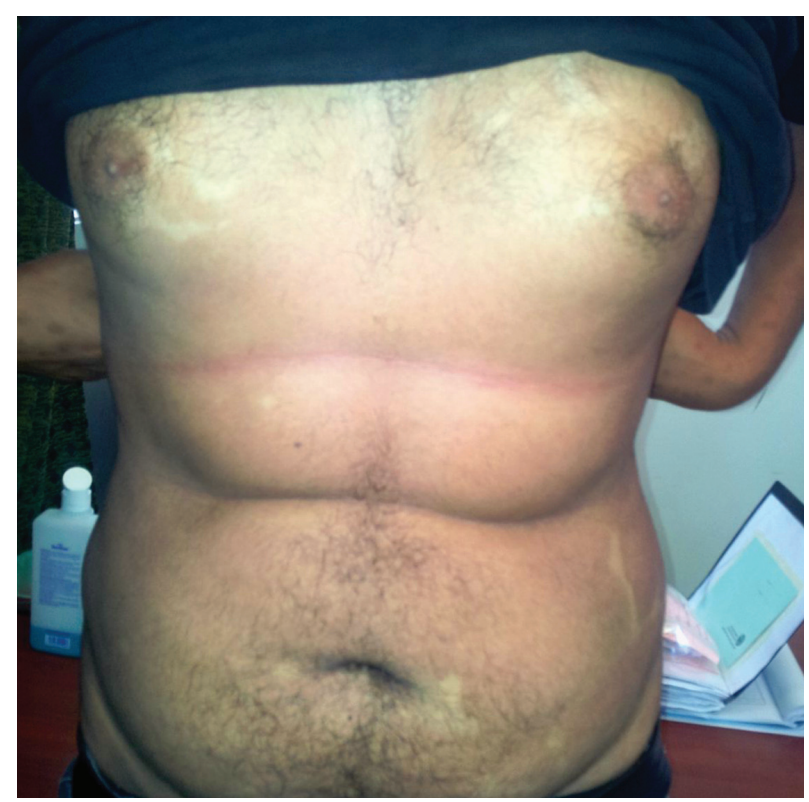

Figure 6. Clearance in the same patient after the last, sixth dose

\section{Discussion}

Psoriasis appears to be mediated by abnormal immune system functioning, including $T$ lymphocyte and macrophage activation and release of various cytokins (4-6) such as interleukin 12 (IL-12) and IL-23. IL-12 induces differentiation of CD4+ T Cells into Th1 cells that produce type 1 cytokines such as interferon gamma and tumor necrosis factor a $(7,8)$. IL-23 induces the development of Th17 cells producing proinflammatory cytokine IL-1 (8-10). Therapy for moderate to severe or refectory psoria- sis has been revolutionized with the introduction of biologics in the past 15 years (1821). The first US Food Drug Administration (FDA) biologic approved for plaque psoriasis was Alefacept in January 2003. Ustekinumab was approved in September 2009 (22). This study was designed to assess the clinical benefit and safety of ustekinumab monotherapy in patients with moderate to severe psoriasis. In $56 \%$ of our patients the disease was moderate while in $44 \%$ of them it was severe. The dose of $45 \mathrm{mg}$ of ustekinumab was administered in $71.4 \%$ of our patients while $28.6 \%$ of them received $90 \mathrm{mg}$ dose in contrast to the study by Leonardi CL (2008) where the $50 \%$ of cases received ustekinumab. The baseline PASI score of our patients ranged from 11.4 to 39.8 (mean: 21.1) where $50 \%$ of cases received ustekinumab $45 \mathrm{mg}$ dose and the other $50 \%$ received $90 \mathrm{mg}$ dose.

The dramatic response to ustekinumab, in which PASI decreased to 6.7 after the second dose, was followed by the subsequent response when it reached 2.6 after the sixth dose. After the second dose 50\% improvement was seen in 27 patients (78\%) and 90\% improvement in $8(22 \%)$ patients. The efficacy was also great after the third dose and $75 \%$ improvement was seen in 27 patients (78\%) and $90 \%$ improvement was seen in 25 patients. A significant improvement was achieved after the last, sixth dose in $65 \%$ of cases and the percentage of clearance increased in $24 \%$, as compared with the results of two trials carried by Leonardo CL, where he found PASI 75 improvement in more $50 \%$ of both ustekinumab groups at week $12(67.1 \%$ and $66.7 \%$ in group $45 \mathrm{mg}$ and $66.4 \%$ and $75.7 \%$ in $90 \mathrm{mg}$ group VS 3.1\% and $3.7 \%$ for placebo respectively) $(17,18)$.

Similar response rates after crossover at week 12 from placebo to ustekinumab treatment were also found. Maximal efficacy was observed between weeks 20 and 24 . In the PHOENIX1 trial, the patients who achieved PASI 75 were re-randomized at week 40 to continue or withdraw from treatment until psoriasis recurrence. Partial responders (week 28: PASI 50-74; week 40: <PASI 75 switched to dosing every 8 weeks $(9,17)$. PASI 75 response was better maintained up to at least 1 year in those receiving maintenance ustekinumab than in those withdrawn from treatment, suggesting that long-term therapy is necessary $(9,17)$. 
In conclusion ustekinumab is effective in the treatment of severe cases of psoriasis vulgaris and well tolerated in patients with resistant, moderate to severe psoriasis vulgaris. Additional effects were seen on psoriatic nails and neither reactions nor serious side effects have been reported by the patients or their doctors.

\section{References}

1. Nestle FO, Kaplan DH, Barker J. Psoriasis. New Eng J Med. 2009;361(5):496-509.

2. Christiophers E, Henseter T. Psoriasis type I and type II as subtypes of non pustular psoriasis. In: Roenigk $\mathrm{H}$, Maibach $\mathrm{H}$, editors. Psoriasis. New York: Dekker; 1990. p. 15-21.

3. Vasků V, Bienertová Vasků J, Pávková Goldbergová $M$, Vasků $A$. Three retinoid $x$ receptor gene polymorphism in plaque psoriasis and psoriasis guttata. Dermatology. 2007;214(2):118-24.

4. Menter A, Gottlieb A, Feldman SR, Van Voorhees AS, Leonardi CL, Gordon KB, et al. Guidelines of care for the management of psoriasis and psoriatic arthritis: section 1. Overview of psoriasis and guidelines of care for the treatment of psoriasis with biologics. J Am Acad Dermatol. 2008;58(5):826-50.

5. Gottlieb A, Korman NJ, Gordon KB, Feldman SR, Lebwohl M, Koo JY, et al. Guidelines of care for the management of psoriasis and psoriatic arthritis: section 2. Psoriatic arthritis: overview and guidelines of care for treatment with an emphasis on the biologics. J Am Acad Dermatol. 2008;58(5):851-64.

6. Boker A, Kimball AB, Rolz-Cruz G. Biologicals in the treatment of psoriasis. Curr Opin Investig Drugs. 2007;8(11):939-46.

7. Barlett BL, Tyring SK. Ustekinumab for chronic plaque psoriasis. Lancet. 2008;371(9625):1639-40.

8. Torti DC, Feldman SR. Interleukin-12, interleukin-23, and psoriasis: current prospects. J Am Acad Dermatol. 2007;57(6):1059-68.

9. Reddy M, Davis C, Wong J, Marsters P, Pendley C, Prabhakar U. Modulation of CLA, IL-12R, CD40L, and IL-2pa expression and inhibition of IL-12 and IL-23 induced cytokine secretion by CNTO1275. Cell Immunol. 2007;247(1):1-11.
10. Leonardi CL, Kimball AB, Papp KA, Yeilding N, Guzzo $C$, Wang $Y$, et al. Efficacy and safety of ustekinumab, a human interleukin-12/23 monoclonal antibody, in patients with psoriasis: 76 -wk result from a randomised, double-blind, placebo-controlled trial (PHOENIX1). Lancet. 2008;371(9625):1665-74.

11. Steinman L. A brief history of Th17, the first major revision in Th1/Th2 hypothesis of T cell-mediated tissue damage. Nat Med. 2007;13(2):139-45.

12. Asarch A, Barak O, Loo DS, Gottlieb AB. Th17 cells: a new therapeutic target in inflammatory dermatosis. J Dermatolog Treat. 2008;19(6):318-26.

13. Lebwohl M. Psoriasis. Lancet. 2003;361(9364):1197204.

14. Naldi L, Gambini D. The clinical spectrum of psoriasis. Clin Dermatol. 2007;25(6):510-8.

15. Menter A, Griffiths CE. Current and future management of psoriasis. Lancet. 2007;370(9583):272-84.

16. Griffiths CE, laccarino L, Naldi L, Olivieri I, Pipitone N, Salvarani C, et al. Psoriasis and psoriatic arthritis: immunological aspects and therapeutic guidelines. Clin Exp Rheumatol. 2006;24 (1 Suppl 40);72-8.

17. Papp KA, Langley RG, Lebwohl M, Krueger GG, Szapary $P$, Yeilding $N$, et al. Efficacy and safety of ustekinumab, a human interleukin-12/23 monoclonal antibody in patient with psoriasis: 52-week results from a randomised, double-blind, placebo-controlled trial (PHOENIX2). Lancet 2008;371(9625):1675-84.

18. Menter A, Gottlieb A, Feldman SR, Van Voorhees AS, Leonardi CL, Gordon KB, et al. Guidelines of care for the management of psoriasis and psoriatic arthritis: section 1. Overview of psoriasis and guidelines of care for the treatment of psoriasis with biologics. J Am Acad Dermatol. 2008;58(5):826-50. SAME AS REF 3

19. Ellis CN, Krueger GG; Alefacept Clinical Study Group. Treatment of chronic plaque psoriasis by selective targeting of memory effecter T lymphocytes. N Engl J Med. 2001;345(4):248-55.

20. Papp KA, Carey W. Psoriasis care. New and emerging pharmacologic trends. J Cutan Med Surg. 2010;14 (3):119-29.

21. Weger W. Current status and new development in the treatment of psoriasis and psoriatic arthritis with biological agents. Br J Pharmacol. 2010;160(4):810-20.

22. Nelson AL, Dhimolea E, Reichert JM. Development trends for human monoclonal antibody. Nat Rev Drug Discov. 2010;9(10):767-74. 


\section{Upotreba ustekinumaba u lečenju libijskih pacijenata sa pso- rijazom vulagaris}

\section{Sažetak}

Uvod. Psorijaza je relativno često hronično inflamatorno oboljenje. Klinički se manifestuje uzdignutim, jasno definisanim eritematoznim plakovima sa nepravilnim ivicama i srebrnastim krljuštima. Čini se da psorijaza nastaje usled nenormalnog funkcionisanja imunosistema, uključujući i aktivaciju T-limfocita i makrofaga i oslobađanje različitih citokina, poput interleukina 12 (IL-12) i IL-23. Odnedavno se u lečenju psorijaze koristi novi biološki agens ustekinumab. Cilj naše studije bio je da utvrdimo efikasnost i toleranciju na ustekinumab kod umerene do teške psorijaze vulgaris i da se prate i prijave neželjene reakcije. Materijal i metode. $U$ ovu studiju uključeno je 35 pacijenata starijih od 18 godina sa umerenom do teškom psorijazom. Ustekinumab se može naći u već napunjenim špricevima od 45 $\mathrm{mg} / 0,5 \mathrm{ml}, 90 \mathrm{mg} / 1 \mathrm{ml}$ za supkutano ubrizgavanje shodno telesnoj težini u periodu od 0,4 sedmice i posle svakih 12 sedmica. Daje ga doktor ili specijalizovana medicinska sestra u bolničkim uslovima. Procena stanja pacijenata i poboljšanja sprovedena je posle svake doze pomoću PASI skora (Psoriasis Area and Severity Index - površina psorijaze i indeks težine oboljenja). Rezultati. Ispitivanje je obuhvatilo 35 pacijenata. Početni PASI skor kod naših pacijenata varirao je od 11,4 do 39,8 (srednja vrednost 21,1 ). Došlo je do dramatične reakcije na lečenje ustekinumabom kada je PASI pao na 6,7 posle druge doze, što je praćeno kasnijim reakcijama kada je došao na 2,6 posle šeste doze. Posle druge doze, u $61 \%$ slučajeva došlo je do poboljšanja, a u $11 \%$ lezije su se povukle. Kod poslednje, šeste doze, došlo je do značajnog poboljšanja u 65\% slučajeva a povećao se i procenat kompletnog povlačenja u 24\% slučajeva. Bilo je vidljivo delovanje i na psorijatične promene na noktima i na kraju lečenja došlo je do značajnog poboljšanja u $50 \%$ slučajeva a do kompletnog izlečenja u 24\%. Zaključak. Ustekinumab je efikasan u lečenju teških i rezistentnih slučajeva psorijaze vulgaris. Pacijenti ga dobro podnose. Nisu prijavljenje reakcije niti ozbiljnije nuspojave na lek.

Ključne reči: Psorijaza; Ustekinumab; Dermatološki preparati; Biološka terapija; Ishod terapije; Libija

Received 12.03.2019.

Accepted 19.03.2019. 